\title{
Water requirement on drip irrigated tomatoes grown under shade net house
}

\author{
PRIYANKA SHARMA, MAHESH KOTHARI AND S.S. LAKHAWAT
}

\begin{abstract}
A field experiment was conducted to investigate the effect of irrigation regimes on drip irrigated tomatoes grown under shade net house at the plasticulture farm, CTAE, Udaipur, Rajasthan. Four different levels of drip irrigation equivalent to 100 per cent, 80 per cent, 60 per cent and 40 per cent of crop evapotranspiration $\left(\mathrm{ET}_{\mathrm{c}}\right)$ with five replications based on gravimetric method were tested for determining the crop water requirement inside the shade net house. Tomato (Lycopersicon esculentum Mill., badshah variety) plants were grown under the shade net house of 50 per cent shade and results are compared with the open cultivation system where the $\mathrm{ET}_{\mathrm{c}}$ was calculated by Penman-Monteith (PM) method. The results revealed that the optimum water requirement for the tomato under the shade net house is around 80 per cent of $\mathrm{ET}_{\mathrm{c}}$ outside the shade net house. Based on this, the actual irrigation water could be recommended between 1.62 and $4.58 \mathrm{~mm} \mathrm{day}^{-1}$ for tomato crop in the shade net house.
\end{abstract}

KEY WORDS : Drip irrigation, Water requirement, Shade net house

How to cite this Article : Sharma, Priyanka, Kothari, Mahesh and Lakhawat, S.S. (2015). Water requirement on drip irrigated tomatoes grown under shade net house. Engg. \& Tech. in India, 6 (1) : 12-18. 